\title{
Pengaruh Kualitas Audit Terhadap Manajemen Laba (Studi Kasus Pada Perusahaan Perbankan yang Terdaftar di Bursa Efek IndonesiaTahun 2014-2016)
}

\author{
Rismansyah \\ Manajemen, Fakultas Ekonomi Universitas PGRI Palembang, \\ Email : rismansyah@univpgri-palembang.ac.id
}

\begin{abstract}
ABSTRAK
Penelitian ini bertujuan untuk mengetahui bagaimana pengaruh kualitas audit terhadap manajemen laba pada perusahaan perbankan yang terdaftar di bursa efek Indonesia. Teknik pengumpulan data yang digunakan dalam penelitian ini adalah Field research, data yang diperoleh dalam penelitian ini adalah dengan penelusuran data sekunder. Berdasarkan hasil uji koefisien diterminasi menunjukkan bahwa nilai $R^{2}$ adalah 0,238 , merupakan pengkuadratan dari koefisien korelasi yaitu $0,487 X$ $0,487=0,237$. Berikut ini untuk menghitung nilai koefisien diterminasi $\mathrm{KD}=0,237 \times 100 \%=23,7 \%$, menunjukkan bahwa nilai koefisien diterminasi sebesar 23,7\%. Dengan demikian, dapat disimpulkan bahwa variabel independen yaitu kualitas audit berpengaruh sebesar $23,7 \%$ terhadap manajemen laba, sedangkan $100-23,7 \%$ sisanya sebesar $76,3 \%$ dijelaskan oleh variabel-variabel yang tidak termasuk dalam penelitian ini. Dari hasil penelitian bahwa kualitas audit mempunyai nilai probabilitas signifikansi terhadap sebesar 0,000 lebih kecil dari $0,05(0,000<0,05)$ artinya Ho ditolak, Ha diterima maka dapat disimpulkan bahwa terdapat pengaruh antara kualitas audit terhadap manajemen laba perusahaan perbankan yang terdaftar di bursa efek Indonesia (BEI) pada tahun 2014-2016.
\end{abstract}

Kata Kunci : Pengaruh Kualitas Audit, Manajemen Laba

\section{A. PENDAHULUAN}

1. Latar Belakang Penelitian

Menurut Kane dan Velury (2005).

Kualitas audit adalah suatu pemeriksaan yang telah dilakukan oleh auditor. Berdasarkan Standar Profesional Akuntan Publik (SPAP) audit yang dilaksanakan auditor dikatakan berkualitas, jika memenuhi ketentuan atau standar pengauditan. Standar pengauditan mencakup mutu professional, auditor independen, pertimbangan (judgement) yang digunakan dalam pelaksanaan audit dan penyusunan laporan audit. Manajemen laba adalah campur tangan dalam proses pelaporan keuangan eksternal dengan tujuan untuk menguntungkan diri sendiri. Manajemen laba adalah salah satu faktor yang dapat mengurangi kredibilitas laporan keuangan, manajemen laba menambah bias dalam laporan keuangan dan dapat mengganggu pemakai laporan keuangan yang mempercayai angka laba hasil rekayasa tersebut sebagai angka laba tanpa rekayasa. (Setiawati dan Na'im, 2000 Serta Rahmawati dkk, 2006).

BEI (Bursa Efek Indonesia) merupakan gabungan dari Bursa Efek atau pasar modal yaitu Bursa Efek Jakarta ( Jakarta Stock Exchange ) dan Bursa Efek Surabaya (Surabaya Stock Exchange) dan Cabang Bursa Efek Palembang alamat, Jl. Bangau No.60, 9 llir, llir Timur II, Kota Palembang, Sumatera Selatan 30114. Bursa Efek Indonesia telah menjadi bagian penting dari berkembangnya perekonomian Indonesia. BEI sebagai salah satu pasar modal yang dapat dijadikan alternatif pendanaan bagi semua sektor perusahaan di Indonesia. Terdapat seluruh perusahaan besar diberbagai sektor 
temasuk sektor perbankan, dikarenakan peneliti meneliti di BEl.

2 Rumusan Masalah

Berdasarkan latar belakang di atas, maka rumusan masalah penelitian ini adalah bagaimana pengaruh kualitas audit terhadap manajemen laba pada perusahaan perbankan yang terdaftar di bursa efek Indonesia?

\section{B. TINJAUAN PUSTAKA}

1. Audit

1.1 Pengertian Audit

Menurut Whittington, O. Ray dan Kurt Pann (2012:4), Audit merupakan pemeriksaan laporan keuangan perusahaan oleh perusahaan akuntan publik yang independen. Audit terdiri dari penyelidikan mencari catatan akuntansi \& bukti lain yang mendukung laporan keuangan tersebut.

Mulyadi (2014), Secara umum auditing adalah suatu proses sistematik untuk memperoleh dan mengevaluasi bukti secara objektif mengenai pernyataan- pernyataan tentang kegiatan dan kejadian ekonomi, dengan tujuan untuk menetapkan tingkat kesesuaian antara pernyataan-pernyataan tersebut dengan kriteria yang telah ditetapkan, serta penyampaian hasil-hasilnya kepada pemakai yang berkepentingan. Defenisi auditing secara umum tersebut memiliki unsur- unsur yang diuraikan berikut ini.

Kriteria yang telah ditetapkan Mulyadi (2014:10), kriteria atau standar yang dipakai sebagai dasar untuk menilai pernyataan (yang berupa hasil proses akuntansi) dapat berupa:

a. Peraturan yang ditetapkan oleh suatu badan legislative

b. Anggaran atau ukuran prestasi lain yang ditetapkan oleh manajemen

c. Prinsip akuntansi berterima umum di Indonesia (generally accepted

principles)

Auditor

accounting

independen

menggunakan kriteria prinsip akuntansi berterima umum di Indonesia dalam menilai laporan keuangan yang disajikan oleh perusahaan. Penyampaian hasil, Penyampaian hasil auditing sering disebut dengan atestasi (attestation). Penyampaian hasil ini dilakukan secara tertulis dalam bentuk laporan audit (audit report). Atestasi dalam bentuk laporan tertulis ini dapat menaikan atau menurunkan tingkat kepercayaan pemakai informasi keuangan atas asersi yang dibuat oleh pihak yang diaudit. Sebaliknya, jika auditor independen menyatakan bahwa laporan keuangan auditan tidak wajar, maka kepercayaan pemakai laporan keuangan atas laporan tersebut akan sangat berkurang atau hilang. Dalam suatu dunia bisnis, pemakai yang berkepentingan terhadap laporan audit adalah para pemakai informasi keuangan seperti: pemegang saham, manajemen, kreditur, calon investor dan kreditur, organisasi buruh dan kantor pelayanan pajak.

\subsection{Auditing Ditinjau Dari Sudut Profesi Akuntan Publik \\ Mulyadi (2014), Ditinjau dari} sudut profesi akuntan publik, auditing adalah pemeriksaan (examination) secara objektif atas laporan keuangan suatu perusahaan atau organisasi lain dengan tujuan untuk menentukan apakah laporan keuangan tersebut menyajikan secara wajar, dalam semua hal yang material, posisi keuangan dan hasil perusahaan atau organisasi tersebut. Buku ini membahas auditing ditinjau dari sudut pandang profesi akuntan publik. Auditor yang melaksanakan audit atas laporan keuangan historis disebut dengan auditor independen. Dalam 
buku ini, istilah auditor jika tidak diikuti dengan kata pengubah (modifier), dimaksudkan sebagai auditor independen.

Auditor bukan merupakan cabang akuntansi, tetapi merupakan suatu disiplin bebas, yang mendasarkan diri pada hasil kegiatan akuntansi dan data kegiatan yang lain.

\subsection{Jenis-jenis Audit}

Terdapat beberapa jenis-jenis audit yang ditinjau dari luas pemeriksaan. Audit dibagi menjadi dua jenis, yaitu General audit (Pemeriksaan umum) dan special audit (Pemeriksaan khusus). Sedangkan bila ditinjau dari jenis pemeriksaan, audit dibagi menjadi empat jenis, yaitu management audit, compliance audit, Internal audit, dan computer audit Berikut penjelasan masing- masing jenis audit (Sukrisno Agoes, 2008).

1. Dari luasnya pemeriksaan, audit dibedakan atas:

a. General audit (Pemeriksaan Umum)

General audit (Pemeriksaan umum) adalah suatu pemeriksaan umum atas laporan keuangan yang dilakukan KAP independen dengan tujuan untuk bias memberikan pendapat mengenai kewajaran laporan keuangan secara keseluruhan.

b. Special Audit (Pemeriksaan Khusus)

Special Audit (Pemeriksaan khusus) adalah suatu pemeriksaan terbatas (sesuai dengan permintaan auditee) yang dilakukan oleh KAP independen, dan pada akhir pemeriksaannya auditor tidak perlu memberikan pendapat terhadap kewajaran laporan keuangan secara keseluruhan. Pendapat yang diberikan terbatas pada pos atau masalah tertentu yang diperiksa, karena prosedur audit yang dilakukan juga terbatas.

2. Dari jenis pemeriksaan, Audit bisa dibedakan atas

a. Management Audit (Operational Audit)

Management audit (opearational audit) adalah suatu pemeriksaan terhadap kegiatan operasi suatu perusahaan, termasuk kebijakan akuntansi dan kebijakan operasional,untuk mengetahui apakah kegiatan operasi tersebut sudah dilakukan secara efektif, efisien, dan ekonomis.

b. Complience Audit

(Pemeriksaan Ketaatan)

Complience audit

(pemeriksaan ketaatan) merupakan pemeriksaan yang dilakukan untuk mengetahui apakah perusahaan sudah menaati peraturan- peraturan dan kebijakan-kebjiakan yang berlaku, baik yang ditetapkan oleh pihak intern perusahaan (manajemen, dewan komisaris) maupun pihak ekstern (Pemerintah Bapepam, Bank Indonesia, Direktorat Jenderal Pajak, dan Lain-lain). Pemeriksaan bias dilakukan baik oleh KAP maupun bagian internal audit.

c. Internal Audit (Pemeriksaan Intern)

Internal audit (pemeriksaan intern) adalah pemeriksaan yang dilakukan oleh bagian internal audit perusahaan, baik terhadap laporan keuangan dan catatan akuntansi perusahaan, maupun ketaatan terhadap 
kebijakan manajemen yang telah ditentukan.

d. Computer Audit

Computer audit merupakan pemeriksaan oleh KAP terhadap perusahaan yang memproses data akuntansinya dengan menggunakan EDP (Electronic Data Processing system).

Masih menurut sumber yang sama, menurut Sukrisno Agoes (2008), ditinjau dari jenis pemeriksaan maka jenis-jenis audit dapat dibedakan atas:

\section{Audit Operasional (Management} Audit), yaitu suatu pemeriksaan terhadap kegiatan operasi suatu perusahaan, termasuk kebijakan akuntansi dan kebijakan operasional yang telah ditetapkan oleh manajemen dengan maksud untuk mengetahui apakah kegiatan operasi telah dilakukan secara efektif, efisien dan ekonomis.

2.

Pemeriksaan

Ketaatan (Complience Audit),

yaitu suatu pemeriksaan yang dilakukan untuk mengetahui apakah perusahaan telah mentaati peraturan-peraturan dan kebijakan-kebijakan yang berlaku, baik yang ditetapkan oleh pihak intern perusahaan maupun pihak ekstern perusahaan.

3. Pemeriksaan Intern (Internal Audit), yaitu pemeriksaan yang dilakukan oleh bagian internal audit perusahaan yang mencakup laporan keuangan dan catatan akuntansi perusahaan yang bersangkutan serta ketaatan terhadap kebijakan manajemen yang telah ditentukan.

4. Audit Komputer (Computer Audit), yaitu pemeriksaan yang dilakukan oleh Kantor Akuntan Publik (KAP) terhadap perusahaan yang melakukan proses data akuntansi dengan menggunakan sistem Elektronic Data Processing (EDP).

Sedangkan berdasarkan kelompok atau pelaksana audit, jenis audit dibagi 4 yaitu:

1. Auditor Ekstern ; Auditor ekstern/independen bekerja untuk kantor akuntan publik yang statusnya diluar struktur perusahaan yang mereka audi, umumnya auditor ekstern menghasilkan laporan atas financial audit.

2. Auditor Intern : Auditor intern bekerja untuk perusahaan yang mereka audit.

3. Auditor Pajak : Auditor pajak bertugas melakukan pemeriksaan ketaatan wajib pajak yang diaudit terhadap undangundang perpajakan yang berlaku.

4. Auditor Pemerintah ; Tugas auditor pemerintah adalah menilai kewajaran informasi keuangan yang disusun oleh instansi pemerintahan.

2. Kualitas Audit

2.1 Pengertian Kualitas Audit

Menurut Mathius Tandiontong (2016), para pakar dibidang manajemen kualitas mendefenisikan kualitas seperti Joseph M. Juran "Kualitas adalah kebugaran untuk penggunaan atau tujuan;" Philip B. Crosby" Kualitas adalah kompormansi terhadap permintaan"; W. Edward Deming" Tingkat kesederajatan dan defisiensiabilitas yang dapat diprediksi dengan biaya rendah dan sesuai untuk pasar ".

Berdasarkan defenisi-defenisi tersebut di atas, dapat disimpulkan bahwa kualitas memiliki ciri-ciri sebagi berikut, yaitu a) sesuatu dianggap berkualitas jika sesuai 
dengan persyaratan-persyaratan tertentu, b) fitur dan karateristik produk atau jasa dapat memenuhi harapan pelanggan baik dari aspek marketing, engineering, produksi dan pemeliharaan.

Kualitas audit dapat diartikan sebagai bagus tidaknya suatu pemeriksaan yang telah dilakukan oleh auditor. Berdasarkan Standar Profesional Akuntan Publik (SPAP) audit yang dilaksanakan auditor dikatakan berkualitas, jika memenuhi ketentuan atau standar pengauditan. Standar pengauditan mencakup mutu professional, auditor independen, pertimbangan (judgement) yang digunakan dalam pelaksanaan audit dan penyusunan laporan audit. Audit quality oleh Kane dan Velury (2005) Serta Simanjuntak (2008), didefinisikan sebagai tingkat kemampuan kantor akuntan dalam memahami bisnis klien.

Dari pendapat tersebut dapat digambarkan hal-hal penting sebagai berikut :

1. Audit harus dilakukan secara sistematis. Hal ini berarti audit tersebut dilakukan secara terencana dan menggunakan orang-orang yang memiliki keahlian dan pelatihan teknis yang memadai sebagai auditor, serta mampu menjadi independensi dalam sikap mental baik dalam penampilan maupun dalam tindakan.

2. Harus memperoleh bukti-bukti untuk dapat membuktikan hasil investigasi serta mengevaluasi apakah informasi keuangan telah sesuai dengan kriteria dan standar akuntansi yang telah ditetapkan.

3. Menetapkan tingkat kesesuaian atau kewajaran antara asersiasersi dalam laporan keuangan klien dengan kriteria atau standar yang telah ditetapkan.
Kriteria atau standar yang dimaksud adalah sesuai prinsip akuntansi yang berlaku umum.

4. Menyampaikan hasil-hasil auditannya kepada para pengguna yang berkepentingan (misalkan kepada managerial ownership), sehingga para pengguna yang berkepentingan dengan informasi tersebut akan dapat membuat keputusan ekonomi.

\subsection{Kualitas Audit Diukur}

Para akademisi umumnya sepakat bahwa audit yang berkualitas harus dilakukan oleh auditor yang kompoten dan independen. Perbedaan antara kompetensi persepsian dan independensi persepsian menunjukan bahwa keduanya, kompetensi dan independensi, adalah dimensi utama dari kualitas audit.

\subsection{Independensi}

Independensi Adalah standar pengauditan yang ensensial untuk menunjukan kredibiltas laporan keuangan yang menjadi tanggung jawab manajemen.ia menekankan bahwa jika akuntan tidak bersikap independen, maka opini yang diberikannya tidak akan memberi tambahan nilai apapun.kewajiban ini harus dijalankan oleh akuntan walaupun hal tersebut harus bertentangan dengan keinginan pihak yang menyewa mereka yang mungkin kemudian akan memecat mereka.

\subsection{Manajemen Laba}

\subsubsection{Pengertian Manajemen Laba}

Keterbatasan laporan keuangan inilah yang menyebabkan terjadinya aktivitas manajemen laba (earnings management) oleh pihak manajemen perusahaan terhadap laporan keuangan perusahaan. Secara umum, manajemen laba didefenisikan 
sebagai upaya manager perusahaan untuk mengintervensi atau mempengaruhi informasi-informasi dalama laporan keuangan dengan tujuan untuk mengelabui stakeholder yang ingin mengetahui kinerja dan kondisi perusahaan (Sulistyanto, 2008). Manajemen laba adalah tindakan yang dilakukan oleh pihak manajemen dengan menaikkan dan menurunkan laba yang dilaporkan dari unit yang menjadi tanggung jawabnya yang tidak mempunyai hubungan kenaikkan atau penurunan profabilitas ekonomis dalam jangka panjang unit tersebut.

\section{PROSEDUR PENELITIAN \\ 1. Populasi dan Sampel}

Populasi dalam sampel penelitiann ini adalah perusahaan perbankan sesuai dengan kelompok industrinya yang terdaftar pada Bursa Efek Indonesia (BEI). Periode pengamatan yang digunakan adalah tahun 2014-2016. Penentuan sampel perusahaan menggunakan purposive sampling, yaitu pengambilan sampel dengan memperhatikan kriteria-kriteria tertentu.

Adapun Kriteria-Kriteria yang harus dipenuhi untuk menjadi sampel penelitian adalah:

1. Perusahaan perbankan (terdaftar) BEI di (Bursa Efek Indonesia) sejak 31 Desember 2014 sampai 31 Desember 2016 dan tidak delisting selama periode penelitian.

2. Menerbitkan laporan keuangan auditan (audited financial statement) untuk periode yang berakhir pada tanggal 31 Desember setiap tahunnya secara berturut-turut dalam periode 2014-2016

3. Mencantumkan nama KAP yang mengaudit laporan keuangannya.

Tabel 1 Kriteria Penentuan Sampel Penelitian

\begin{tabular}{|c|c|c|c|}
\hline No & Kriteria & $\begin{array}{c}\text { Tahun Pengamatan } \\
\text { (2014 s.d 2016) } \\
\text { 3thn }\end{array}$ & $\begin{array}{c}\text { Jumlah } \\
\text { Sampel }\end{array}$ \\
\hline 1 & $\begin{array}{l}\text { Perusahaan perbankan (terdaftar) di Bursa Efek } \\
\text { Indonesia (BEI) sejak 1 januari 2013 sampai 31 } \\
\text { Desember 2015 dan tidak delisting selama }\end{array}$ & 29 & 8 \\
\hline 2 & $\begin{array}{l}\text { Menerbitkan laporan keuangan auditan } \\
\text { audited financial statement) untuk periode }\end{array}$ & 9 & 7 \\
\hline $\begin{array}{l}\text { yang berakhir pada tanggal 31Desember } \\
3\end{array}$ & $\begin{array}{l}\text { Mencantumkan nama KAP yang } \\
\text { mengaudit laporan keuangannya. }\end{array}$ & 11 & 3 \\
\hline J u m I a h & $\mathbf{2 0}$ & $\mathbf{1}$ \\
\hline
\end{tabular}

Sumber : Data Sekunder diolah 2017

Perusahaan perbankan yang terdaftar di Bursa Efek Indonesia selama tahun 2014-2016 adalah 29 bank. Berdasarkan kriteria pemilihan sampel yang telah dilakukan, maka menghasilkan sampel sebanyak 20 bank. Analisis data dilakukan dengan menggunakan penggabungan data atau pooling data, sehingga jumlah unit analisis data untuk tahun 20142016 adalah 60 unit $(3 \times 20)$.

Adapun

perusahaanperusahaan yang dijadikan sampel dalam penelitian ini dapat dilihat pada tabel 2 berikut ini :

\section{Tabel 2 Daftar Sampel Penelitian}




\begin{tabular}{|c|c|c|c|}
\hline No & Tahun & Nama Bank & Kode Bank \\
\hline 1 & $2014-2016$ & Bank AGRO & AGRO \\
\hline 2 & $2014-2016$ & Bank Capital Indonesia & BACA \\
\hline 3 & $2014-2016$ & Bank Central Asia & BBCA \\
\hline 4 & $2014-2016$ & Bank Bukopin & BBKP \\
\hline 5 & $2014-2016$ & Bank Negara Indonesia & BBNI \\
\hline 6 & $2014-2016$ & Bank Nusantara & BBNP \\
\hline 7 & $2014-2016$ & Bank Rakyat Indonesia & BBRI \\
\hline 8 & $2014-2016$ & Bank Tabungan Negara & BBTN \\
\hline 9 & $2014-2016$ & Bank Mutiara & BCIC \\
\hline 10 & $2014-2016$ & Bank Pundi Indonesia & BEKS \\
\hline 11 & $2014-2016$ & Bank Kesawan & BKSW \\
\hline 12 & $2014-2016$ & Bank Mandiri & BMRI \\
\hline 13 & $2014-2016$ & Bank Bumi Arta & BNBA \\
\hline 14 & $2014-2016$ & Bank CIMB Niaga & BNGA \\
\hline 15 & $2014-2016$ & Bank Internasional & BNII \\
\hline 16 & $2014-2016$ & Bank Permata & BNLI \\
\hline 17 & $2014-2016$ & Bank Tabungan Pensiunan & BTPN \\
\hline 18 & $2014-2016$ & Bank OCBC NISP & NISP \\
\hline 19 & $2014-2016$ & Bank Mega & MEGA \\
\hline 20 & $2014-2016$ & Bank Victoria & BVIC \\
\hline
\end{tabular}

Sumber : data sekunder diolah 2017

\section{Teknik Pengumpulan Data}

Teknik pengumpulan data yang digunakan dalam penelitian ini adalah Field research, data yang diperoleh dalam penelitian ini adalah dengan penelusuran data sekunder. Yang diperoleh melalui metode dokumentasi dilakukan dengan mengumpulkan sumber-sumber data dokumentar seperti laporan keuangan audit perusahaan yang menjadi sampel penelitian. Berupa laporan keuangan perusahaan yang telah diaudit tahun 2014, 2015, dan 2016. Data-data tersebut dapat diperoleh langsung daftar menjadi anggota BEI (Bursa Efek Indonesia) dan melalui website www.idx.co.id . Library research, Peneliti mendapatkan informasi tambahan yang berkaitan dengan penelitian melalui buku, artikel,internet dan perangkat lainnya yang berkaitan dengan kualitas audit.

\section{Teknik Analisis Data}

Analisis kuantitatif dalam suatu peneliti dapat didekati dari sudut pendekatan, yaitu dengan analisis kuantitatif secara deskritif statistik, peneliti perlu memperhatikan terlebih dahulu datanya.

\section{HASIL DAN PEMBAHASAN}

1. Hasil Penelitian

1.1 Deskripsi Objek Penelitian

Populasi penelitian ini adalah seluruh perusahaan perbankan yang terdaftar di BEI (Bursa Efek Indonesia) pada tahun 20142016. Jumlah populasi penelitian sebanyak 29 perusahaan perbankan. Pemilihan perusahaan 
dikarenakan karakteristik industri perbankan berbeda dengan industri lainnya. Untuk melakukan manajemen laba supaya perusahaan mereka dapat memenuhi kriteria yang disyaratkan oleh Bank Indonesia (Setiawati dan Na'im, 2001 serta Nasution dan Setiawan, 2007). Sampel dalam penelitian ini adalah perusahaan perbankan yang secara konsisten terdaftar di Bursa Efek Indonesia pada tahun $2014 \quad$ - 2016, mempublikasikan laporan keuangan tahunan pada periode 31 Desember 2014 - 31 Desember 2016, tidak mengalami rugi selama periode pengamatan, serta data tersedia lengkap, baik untuk mendeteksi manajemen laba. Pemilihan sampel berdasarkan kriteriakriteria tersebut menghasilkan sampel sebanyak 20 bank. Sehingga jumlah unit analisis data pada penelitian ini adalah 60 item $=(3 \times 20)$.

\subsection{Analisis Statistik Deskriptif}

Hasil statistik deskriptif atau gambaran untuk masing-masing variabel dewan komisaris independen, komite audit independen, dan kepemilikan manajerial serta manajemen laba yang diproksikan dengan discretionary accruals.
1.3 Analisis Inferensial

1.3.1 Uji Asumsi Klasik

Uji asumsi klasik harus dilakukan dalam penelitian ini untuk menguji apakah data memenuhi asumsi klasik. Hal ini dilakukan untuk menghindari terjadinya estimasi yang bias, mengingat tidak semua data dapat diterapkan regresi. Pengujian yang dilakukan dalam penelitian ini adalah uji normalitas, uji regresi liniear sederhana.

\subsubsection{Uji Normalitas}

Uji normalitas bertujuan untuk menguji apakah dalam model regresi variabel independen dan dependen, keduanya mempunyai distribusi data yang normal atau tidak. Ada dua cara untuk mendeteksi apakah residual berdistribusi normal atau tidak yaitu dengan analisis grafik dan uji statistik. Uji normalitas dalam penelitian ini menggunakan uji statistik non-parametrik Kolmogorov- mirnov (K-S). Suatu regresi yang memiliki distribusi data residual normal apabila hasil dari uji K-S memiliki tingkat signifikansi lebih besar dari (Sig > 0,05) (Ghozali, 2011). Hasil uji normalitas dapat dilihat pada tabel 3 berikut ini:

Tabel 3 Hasil Uji Normalitas One-Sample Kolmogorov-Smirnov Test

\begin{tabular}{|c|l|c|c|}
\hline No & \multicolumn{1}{|c|}{ Variabel } & $\begin{array}{c}\text { Asymp. Sig. (2- } \\
\text { tailed) }\end{array}$ & Keterangan \\
\hline 1 & Kualitas Audit & $0,320>0,05$ & Normal \\
\hline 2 & Manajemen Laba & $0,215>0,05$ & Normal \\
\hline
\end{tabular}

a. Test distribution is Normal.

b. Calculated from data.

Sumber : Data Sekunder diolah 2017 
Tabel 3 menunjukkan perhitungan variabel manajemen laba bahwa nilai Kolmogorov-Smirnov adalah 2,887 dengan nilai signifikansi 0,215 sedangkan perhitungan variabel kualitas audit bahwa nilai Kolmogorov-Smirnov adalah 3,736 dengan nilai signifikansi 0,320 . Model regresi dikatakan normal apabila nilai signifikansi dari nilai kolmogorov-smirnov lebih dari taraf signifikansi 5\% $(0,05)$. Nilai signifikansi variabel manajemen laba
$(0,215>0,05)$ dan Nilai signifikansi variabel manajemen laba $(0,320>0,05)$ maka residual regresi terdistribusi dengan normal atau dapat dikatakan bahwa uji normalitas data terpenuhi.

1.4. Analisis Regresi Linier Sederhana

1.4.1 Persamaan Regresi

Untuk mengetahui pengaruh kualitas audit terhadap manajemen laba, nilai taksiran koefisien regresi a dan $b$ dilihat pada tabel 4.2 berikut :

Tabel 4 Hasil Uji Persamaan Regresi

Coefficients $^{a}$

\begin{tabular}{|l|c|c|c|c|c|}
\hline \multirow{2}{*}{ Variabel } & \multicolumn{2}{|c|}{$\begin{array}{c}\text { Unstandardized } \\
\text { Coefficients }\end{array}$} & $\begin{array}{c}\text { Standardized } \\
\text { Coefficients }\end{array}$ & \multirow{2}{*}{ T } & \multirow{2}{*}{ Sig. } \\
\cline { 2 - 4 } & B & Std. Error & Beta & & \\
\hline (Constant) &,- 726 &, 117 & & $-6,207$ &, 000 \\
Kualitas Audit &, 562 &, 132 &, 487 & 4,249 &, 000 \\
\hline
\end{tabular}

Dependent Variable: Manajemen Laba

Sumber : Data Sekunder diolah (2017)

Dari tabel 4 di atas maka dapat dibuat persamaan regresi sebagai berikut

$$
Y=-0,726+0,562 X+e
$$

Dari persamaan regresi di atas menunjukan bahwa nilai koefisien konstanta $-0,726$ memiliki arti bahwa pada saat variabel independen bernilai 0 , maka nilai perusahaan mengalami peningkatan sebesar 0,726 satuan. Kemudian koefisien regresi variabel pembagian dividen (X) mempunyai arah positif sebesar 0,562, menunjukan bahwa jika variabel pembagian dividen meningkat $1 \%$, maka nilai perusahaan akan mengalami peningkatan sebesar 0,562 kali dengan ketentuan variabel lain konstanta.

\subsubsection{Koefisien Korelasi}

Menurut Sujarweni (2014) koefisien korelasi digunakan untuk mengetahui hubungan antar variabel. Nilai koefisien korelasi dapat dilihat pada nilai $\mathrm{R}$ yang ditunjukkan pada tabel 4.3 berikut :

Tabel 5 Hasil uji koefisien korelasi Model Summary ${ }^{\mathrm{b}}$

\begin{tabular}{|c|c|c|c|}
\hline $\mathrm{R}$ & $\mathrm{R}$ Square & Adjusted R Square & $\begin{array}{c}\text { Std. } \\
\text { Error of the } \\
\text { Estimate }\end{array}$ \\
\hline $0,487^{\mathrm{a}}$ & 0,237 & 0,224 & 0,42169 \\
\hline
\end{tabular}

Sumber : Data Sekunder diolah (2017). 
Dari hasil uji di atas dapat dilihat bahwa nilai $R$ sebesar 0,487 , yang menunjukkan bahwa derajat hubungan (korelasi) antara variabel indenpenden dengan variabel dependen sebesar 48,7\%. Ini artinya bahwa kualitas audit mempunyai hubungan sedang dengan manajemen laba. Hubungan variabel independen dengan variabel dependen dikatakan sedang karena berada pada interval 0,21 sampai 0,40.

1.4.3 Uji koefisien Diterminasi $\left(\mathrm{R}^{2}\right)$

Secara umum $\mathrm{R}^{2}$ digunakan untuk melihat seberapa besar tingkat pengaruh variabel independen terhadap variabel dependen. Pengujian koefisien diterminasi dapat pada tabel 6 berikut :

Tabel 6 Hasil Uji Koefisien Diterminasi Model Summaryb

\begin{tabular}{|c|r|r|rr|}
\hline$R$ & R Square & Adjusted R Square & Std. Error of the Estimate \\
\hline $0,487^{\mathrm{a}}$ & 0,237 & 0,224 & & 0,42169 \\
\hline
\end{tabular}

Berdasarkan hasil uji koefisien diterminasi menunjukkan bahwa nilai $R^{2}$ adalah 0,238 , merupakan pengkuadratan dari koefisien korelasi yaitu $0,487 \mathrm{X}$ $0,487=0,237$. Berikut ini untuk menghitung nilai koefisien diterminasi $\mathrm{KD}=0,237 \times 100 \%=$ $23,7 \%$.

Dari perhitungan di atas menunjukkan bahwa nilai koefisien diterminasi sebesar 23,7\%. Dengan demikian, dapat disimpulkan bahwa variabel independen yaitu kualitas audit berpengaruh sebesar $23,7 \%$ terhadap manajemen laba, sedangkan $100-23,7 \%$ sisanya sebesar $76,3 \%$ dijelaskan oleh variabel-variabel yang tidak termasuk dalam penelitian ini.

\subsubsection{Analisis Regresi}

Analisis regresi digunakan untuk melihat pengaruh antara kualitas audit terhadap manajemen laba dapat dilihat pada tabel 7 berikut :

Tabel 7 Analisis Kualitas Audit Terhadap Manajemen Laba

Coefficients $^{a}$

\begin{tabular}{|l|c|c|c|c|c|}
\hline \multirow{2}{*}{ Variabel } & \multicolumn{2}{|c|}{$\begin{array}{c}\text { Unstandardized } \\
\text { Coefficients }\end{array}$} & $\begin{array}{c}\text { Standardize } \\
\text { d }\end{array}$ & \multirow{2}{*}{ T } & \multirow{2}{*}{ Sig. } \\
\cline { 2 - 4 } & $\mathrm{B}$ & Std. Error & Beta & & \\
\hline $\begin{array}{l}\text { (Constant) } \\
\text { KUALITAS AUDIT }\end{array}$ &,- 726 &, 117 & & $-6,207$ &, 000 \\
\cline { 2 - 6 } &, 562 &, 132 &, 487 & 4,249 &, 000 \\
\hline
\end{tabular}

Dependent Variable: MANAJEMEN LABA

Sumber : Data Sekunder diolah (2017)

Dari tabel di atas dapat diketahui bahwa kualitas audit mempunyai nilai probabilitas signifikansi sebesar 0,000 lebih kecil 
dari $0,05 \quad(0,000<0,05)$ artinya $\mathrm{Ho}$ ditolak, Ha diterima, maka dapat disimpulkan bahwa terdapat pengaruh antara kualitas audit terhadap manajemen laba perusahaan perbankan yang terdaftar di bursa efek Indonesia.

\section{Pembahasan}

Berdasarkan hasil penelitian di atas objek penelitian merupakan permasalahan yang akan diteliti. Objek dari penelitian ini adalah kualitas audit terhadap manajemen laba pada perusahaan perbankan yang terdaftar di BEI (bursa efek Indonesia) pada tahun 2013-2015. Populasi penelitian ini adalah seluruh perusahaan perbankan yang terdaftar di BEl (Bursa Efek Indonesia) pada tahun 2013-2015, jumlah populasi penelitian sebanyak 29 perusahaan perbankan. Sampel dalam penelitian ini adalah perusahaan perbankan yang secara konsisten terdaftar di Bursa Efek Indonesia yang mempublikasikan laporan keuangan tahunan pada periode 31 Desember 2014 - 31 Desember 2016, tidak mengalami rugi selama periode pengamatan, serta data tersedia lengkap, baik untuk mendeteksi manajemen laba. Pemilihan sampel berdasarkan criteria - kriteria tersebut menghasilkan sampel sebanyak 20 bank. Sehingga jumlah unit analisis data pada penelitian ini adalah 60 unit $=(3 \times 20)$.

Hasil analisis deskriptif dapat diketahui bahwa rata-rata untuk variabel independen kualitas audit dengan adalah sebesar 0,7833 dengan nilai maksimum sebesar 1,00 dan nilai minimum sebesar 0,00 . Untuk variabel dependen manajemen laba adalah sebesar $-0,2861$ dengan nilai maksimum sebesar 0,00 dan nilai minimum sebesar $-1,85$. Standar deviasi lebih rendah dari rata-rata menunjukkan sebaran data untuk variabel kualitas audit dan manajemen laba sudah baik.

Hasil perhitungan menunjukkan bahwa perusahaan perbankan pada tahun 2014 sampai dengan tahun 2016 melakukan manajemen laba, baik dengan pola menaikkan laba (income increasing) maupun menurunkan laba (income decreasing). Nilai manajemen laba tertinggi yaitu sebesar $-3,25496$ dimiliki oleh Bank Bumi Arta pada tahun 2014, sedangkan nilai manajemen laba terendah yaitu sebesar-0,00057 dimiliki oleh Bank Victoria pada tahun 2016.

Analisis deskriptif variabel independen yang ketiga adalah kepemilikan manajerial (KM) yang pada penelitian ini menggunakan variabel dummy. Apabila terdapat proporsi kepemilikan saham oleh manajerial, maka diberi nilai 1, sedangkan apabila tidak terdapat kepemilikan manajerial, maka diberi nilai 0. Dimana untuk KAP yang berasal dari Big Four diberikan nilai 1, dan KAP yang bukan berasal dari Big Four diberikan nilai 0 .

Pada perhitungan variabel manajemen laba bahwa nilai Kolmogorov-Smirnov adalah 2,887 dengan nilai signifikansi 0,215 sedangkan perhitungan variabel kualitas audit bahwa nilai Kolmogorov-Smirnov adalah 3,736 dengan nilai signifikansi 0,320 . Model regresi dikatakan normal apabila nilai signifikansi dari nilai kolmogorovsmirnov lebih dari taraf signifikansi $5 \%(0,05)$. Nilai signifikansi variabel manajemen laba $(0,215>0,05)$ dan Nilai signifikansi variabel kualitas laba $(0,320>0,05)$, maka residual regresi terdistribusi dengan normal atau dapat di katakan bahwa uji normalitas data terpenuhi. 
Dari persaman regresi diatas menunjukan bahwa nilai koefisien konstanta -0,726 memiliki arti bahwa pada saat variabel independen bernilai 0 , maka nilai perusahaan mengalami peningkatan sebesar $-0,726$ satuan. Kemudian koefisien regresi variabel pembagian dividen (X) mempunyai arah positif sebesar 0,562, menunjukan bahwa jika variabel pembagian dividen meningkat $1 \%$, maka nilai perusahaan akan mengalami peningkatan sebesar 0,562 kali dengan ketentuan variabel lain konstanta

$$
Y=-0,726+0,662 X+0,42169
$$

Dari hasil uji di atas dapat dilihat bahwa nilai $R$ sebesar 0,487, yang menunjukkan bahwa derajat hubungan (korelasi) antara variabel indenpenden dengan variabel dependen sebesar $48,7 \%$. Ini artinya bahwa kualitas audit mempunyai hubungan lemah dengan manajemen laba. Hubungan variabel independen dengan variabel dependen dikatakan sedang karena berada pada interval 0,21 sampai 0,40 .

Dari perhitungan diatas menunjukkan bahwa $\mathrm{KD}=0,237 \mathrm{x}$ $100 \%=23,7 \%$ nilai koefisien diterminasi sebesar 23,7\%. Dengan demikian, dapat disimpulkan bahwa variabel independen yaitu kualitas audit berpengaruh sebesar 23,7\% terhadap manajemen laba, sedangkan 100 - 23,7\% sisanya sebesar 76,3\% dijelaskan oleh variabel-variabel yang tidak termasuk dalam penelitian ini.

Analisis regresi digunakan untuk melihat pengaruh antara kualitas audit terhadap manajemen laba dapat diketahui bahwa kualitas audit mempunyai nilai probabilitas signifikansi sebesar 0,000 lebih kecil dari 0,05 $(0,000<0,05)$ artinya Ho ditolak, Ha diterima, maka dapat disimpulkan bahwa terdapat pengaruh antara kualitas audit terhadap manajemen laba pada bursa efek Indonesia pada tahun 2014-2016.

Berdasarkan penelitian terdahulu menurut Hikmah Is'ada Rahmawati (2013). Dengan judul "Pengaruh Mekanisme Good Corporate Governance (GCG) Terhadap Manajemen Laba Pada Perusahaan Perbankan Yang Terdaftar Di Bursa Efek Indonesia Tahun 2009-2011" maka variabel komite audit independen tidak berpengaruh signifikan terhadap variabel manajemen laba Pada Perusahaan Perbankan Yang Terdaftar Di Bursa Efek dan variabel kepemilikan manajerial tidak berpengaruh signifikan terhadap variabel manajemen laba Pada Perusahaan Perbankan Yang Terdaftar Di Bursa Efek Tahun 20092011".

Menurut Ingrid Christiani, Yeterina Widi Nugrahanti. (2014). Dengan judul "Pengaruh Kualitas Audit Terhadap Manajemen laba PT Kimia Farma Tbk" maka Hasil penelitian menunjukkan bahwa ukuran KAP tidak berpengaruh terhadap manajemen laba. Spesialisasi industri auditor berpengaruh negatif terhadap manajemen laba. Dari keempat variabel kontrol yang digunakan dalam penelitian ini, hanya arus kas operasi dan pertumbuhan yang berpengaruh terhadap manajemen laba, sementara kedua variabel lainnya, yaitu ukuran perusahaan dan leverage, tidak berpengaruh.

E. KESIMPULAN DAN SARAN

1. Kesimpulan

a. Populasi penelitian ini adalah seluruh perusahaan perbankan yang terdaftar di Bursa Efek Indonesia (BEI) pada tahun 2014-2016. Jumlah populasi 
penelitian sebanyak 29 perusahaan perbankan, Pemilihan sampel berdasarkan kriteria- kriteria tersebut menghasilkan sampel sebanyak 20 bank penelitian ini adalah 60 unit $=(3 \times 20)$. Nilai signifikansi variabel manajemen laba 0,215 $>0,05)$ dan. Nilai signifikansi variabel kualitas laba $(0,320>$ $0,05)$ maka residual regresi terdistribusi dengan normal atau dapat dikatakan bahwa uji normalitas data terpenuhi. Persamaan regresi $Y=-0,726+$ $0,662 X+0,42169$. Hubungan (korelasi) antara variabel indenpenden dengan variabel dependen sebesar 48,7\%, mempunyai hubungan lemah karena berada pada interval 0,21 sampai 0,40. sedangkan $100-$ $23,7 \%$ sisanya sebesar $76,3 \%$ dijelaskan oleh variabel-variabel yang tidak termasuk dalam penelitian ini.

b. Hasil penelitian di atas bahwa kualitas audit mempunyai nilai probabilitas signifikansi terhadap sebesar 0,000 lebih kecil dari $0,05(0,000<0,05)$ artinya Ho ditolak, Ha diterima maka dapat disimpulkan bahwa terdapat pengaruh antara kualitas audit terhadap manajemen laba perusahaan perbankan yang terdaftar di bursa efek Indonesia (BEI) pada tahun 2014-2016.

\section{Saran}

a. Kualitas audit independen dalam penelitian ini terbukti berpengaruh terhadap manajemen laba, maka diharapkan menjadi Ukuran KAP Big Four dan KAP lebih meningkatkan pengawasan terhadap pihak manajemen agar informasi yang terkandung dalam laporan keuangan semakin baik dan berkualitas.

b. Berdasarkan hasil penelitian ini, dapat disarankan bagi investor dan masyarakat sebelum melakukan pengambilan keputusan investasi di suatu perusahaan untuk hendaknya lebih memilih perusahaan yang menggunakan spesialisasi industri auditor karena dengan adanya spesialisasi industri auditor dapat membatasi praktik manajemen laba yang terjadi di suatu perusahaan.

\section{DAFTAR PUSTAKA}

Agoes Sukrisno, 2008. Auditing Pemeriksaan oleh Kantor Akuntan Publik jilid satu. Jakarta: Lembaga Penerbit Fakultas Ekonomi Universitas Indonesia.

Ghozali, Imam. 2011. Aplikasi Analisis Multivariate dengan Program IBM SPSS 20. Semarang: Badan Penerbit - Universitas Diponegoro.

Hikmah Is'ada Rahmawati (2013). "PengaruhMekanismeGood Corporate Governance (GCG) Terhadap Manajemen Laba Pada Perusahaan Perbankan Yang Terdaftar DiBursa Efek Indonesia Tahun 2009-2011" Universitas Negeri Semarang. Skripsi.

Ingrid Christiani, Yeterina Widi Nugrahanti. (2014). Pengaruh Kualita Audit Terhadap Manajemen laba. Fakultas Ekonomika dan Bisnis, Universitas Kristen Satya Wacana. Jurnal Akuntansi dan Keuangan. 
Kane, G., \& U. Velury. 2005. The Impact Of Managerial Ownership On The Likelihood Of Provision Of High Quality Auditing Services, Review Of Accounting \& Finance.

Mulyadi, 2014. Auditing. Penerbit Salemba Empat Edisi Ke-6

Mathius Tandiontong, Kualitas Audit Dan Pengukurannya Penerbit ALFABETA. Mulyadi, 2014 Auditing Penerbit Salemba Empat Edisi ke-6.

Setiawati,Lilis dan Ainun Na'im.2000.Manajemen

Laba.Jurnal Ekonomi dan Bisnis Indonesia, Vol.15,No 4,424-441.

Simanjuntak, Piter. 2008. Pengaruh Time Budget Pressure Dan Resiko Kesalahan Terhadap Penurunan Kualitas Audit
(Reduced Audit Qaulity) (Studi Empiris Pada Auditor Kap Di Jakarta). Tesis. Universitas Diponegoro : Semarang.

Sujarweni, Wiratna. 2014. SPSS untukPenelitian. Yogyakarta :PustakaBaru Press.

Sulistyanto,Sri.2008.ManajemenLaba: TeoridanModelEmpiris. Jakarta: Grasindo. Watkins. Ann L, Hillison, William, Morecroft, Susan E. 2004. Audit Quality: A Synthesis Of Theory and Empirical Evidence. Journal Of Accounting Literature, Vol 23 pp.153-193.

Whittington, O. Ray dan Kurt Pany 2012 principles of auditing and other assurance service, 18 th edition, m-c Graw-hill, New York, NY 